\title{
脂質膜の形態形成メカニズムの理解にむけて
}

\author{
菱田 真史 \\ (京都大学 理学研究科 物理学第一教室)
}

\section{Towards the Understanding of Lipid Membrane Formation}

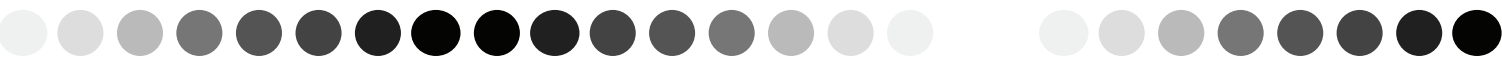

ABSTRACT

How can we understand the formation mechanism of various morphologies of biomembrane? We are trying to understand the formation mechanism from the view point of soft matter physics, i.e., from physical properties of lipid assembly. We have especially studied the mechanism of giant vesicles formation from the lipid film by means of time-resolved Small-Angle X-ray Scattering, and the results suggest that the morphologies of lipid membrane strongly depend on the kinetics of the formation process. Thus, the observation of formation kinetics of various membrane morphologies should become more important to understand the biomembrane formation from soft matter physics. For observing the kinetics of membrane self-assembly, time-resolved measurements of Small-Angle Neutron Scattering and Neutron Spin Echo spectroscopy will make a significant contribution and will shed light on the various morphologies of biomembrane.
\end{abstract}

Mafumi Hishida

Department of Physics, Kyoto University

Keywords: Soft matter physics, Biophysics, Lipid membrane, SAXS, SANS, NSE

1.はじめに

\section{1. 生体膜とソフトマター}

生命は等温で非平衡条件をうまく利用しながら 活動を行っており，その理解は生物学にとどまら ず, 物理学においても重要な課題となっている. 中でも細胞や細胞内オルガネラの形態形成は重要 な問題の一つである。これらの形態を決めている 生体膜は基本的にリン脂質と呼ばれる両親媒性分 子が親水基頭部を外側に，疎水鎖を内側に向ける ようにして二重膜を形成することにより成り立っ ている. 生体中の膜形態はひとつにはタンパク質 が膜に作用して決定しているといわれているが, 一方で脂質の物理的性質の重要性も指摘されてお り，膜の形態形成メカニズムを明らかにするため にはソフトマター物理学的視点から脂質膜の形態 形成に迫ることが不可欠である.

リン脂質をはじめとするソフトマターを研究す る上で重要な特徽は分子スケールの構造とマクロ な構造との間にミセルや二重膜のような数〜数百 $\mathrm{nm}$ スケールの中間階層構造をもち, それがマク ロな物性に大きな影響を与えるということである。 さらに自己組織化によりこれらの中間階層構造が 形成するための相互作用は van der Waals 相互作用 や疎水性相互作用といった熱摇らぎ $k_{B} T$ 程度の相 互作用であるため, 温度や溶媒などの環境のわず かな変化によりその自己組織化構造は劇的に変化
寸る. そこでこういった構造の観測には数 $\AA$ 数 百 $\mathrm{nm}$ スケールの観測に適し，また溶液中でのそ の場観測が可能な X線小角散乱や中性子小角散乱 が威力を発揮する。

\section{2. リン脂質ジャイアントベシクル}

リン脂質分子は一般的に，水中に溶かしただけ で二重膜構造を形成することが知られているが,

リン脂質をただ水中に分散させただけではマルチ ラメラ構造と呼ばれる膜小胞が何重にも入れ子状 に重なった玉祀ぎ状の構造（だいたい数百 $\mathrm{nm}$ 程 度）が形成される。これはリン脂質一水の系での 熱力学的に安定な構造がマルチラメラ構造である ことを示している。では生体膜に見られるような $\mu \mathrm{m}$ スケールで単層の小胞構造（ジャイアント心゙ シクル，細胞サイズリポソーム）はどのように効 率的に形成されるのか。言い換えると, 脂質膜構 造はいかにジャイアントベシクルという準安定な 状態にトラップされ得るのか. 我々はこれまでと くにこのジャイアントベシクルの形成メカニズム に注目して研究を行ってきた。

中でも注目したのが「静置水和法」と呼ばれる, 古くから経験的に知られていたジャイアントベシ クル形成法である[1]. この方法は，あらかじめ基 板上にリン脂質 dry film を作成しておき，それを 水和することで自発的にジャイアントベシクルが 

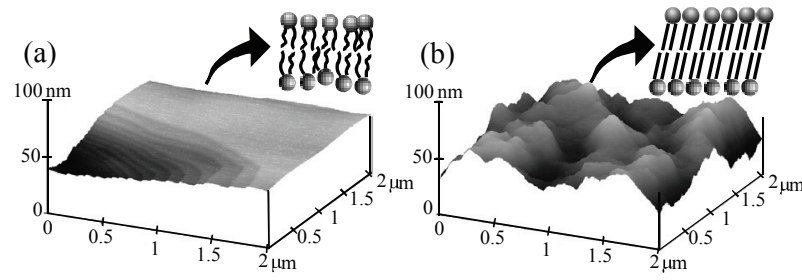

Fig.1 Phospholipid dry films observed by atomic force microscopy.

(a)

Liquid-crystalline phase (DOPC at room temperature), (b) Gel phase (DPPC at room temperature).

形成されるというものである。この方法はジャイ アントベシクルを細胞モデルとして利用しようと するような応用科学的な研究でもよく用いられる 方法であり [2], そのメカニズムを理解することは， いかにして脂質膜が決まった構造を効率的に形成 しているのかというメカニズムの理解だけでなく， どのような条件で最も効率的にジャイアントベシ クルが形成できるかといった応用に向けた技術的 示唆も可能にするものである.

我々のこれまでの研究では特に，静置水和法に よってジャイアントベシクルを形成する際の初期 状態であるリン脂質 dry film の nm $\mu \mathrm{m}$ の構造と, それが水和されたときのジャイアントベシクルヘ の構造変化のキネティクスを，顕微鏡および時分 割 X線小角散乱を用いて観測することによりこの メカニズムに迫ってきた.

\section{2. ジャイアントベシクルの形成メカニズム}

我々はまず, 静置水和法によりジャイアントベ シクルを形成する際の初期状態であるリン脂質 dry film の構造の観測を位相差顕微鏡および原子 間力顕微鏡，さらにX 線反射率測定を用いて行っ た $[3,4]$. その結果, 脂質のアシル鎖が融解し膜内で 分子の流動性のある液晶相では, dry film は $\mu \mathrm{m}$ ス欠 ールで膜面が平滑なテラス状の積層膜構造が，反対 にアシル鎖が結晶化したゲル相では激しい凸凸が見 られることを見出した(Fig.1). またこれらのdry filmの 構造が水和によるジャイアントベシクルの形成効率に 関与しており, テラス構造を作ることがジャイアントベ シクル形成に重要であることを見出した.

さらに続いて, これらのリン脂質 dry film が水和さ れた時, 基板上の積層膜がごのようにジャイアントベ シクルに構造転移していくのかを時分割 X 線小角散 乱を用いて観測した[5]. この転移過程は秒単位での 観測が必要であるため, 十分な X 線強度が得られる よう放射光 X 線 (SPring-8, BL40B2)を用いて実験を 行った. 実験は専用の特殊なセルを作製することで, 基板上に積層した膜の挙動を追った. 観測は乾燥状 態から始め, film がバルク水に浸って十分に時間が たちほとんどシグナルが見えなくなるまで測定を続け た.

脂質が液晶相で dry film がテラス構造をとる場 合の実験結果を Fig.2 に示す.十分に時間がたつ と基板上の積層膜からくる Bragg ピークが消滅し, 膜がほぼ剥がれていることが分かる。このときジ

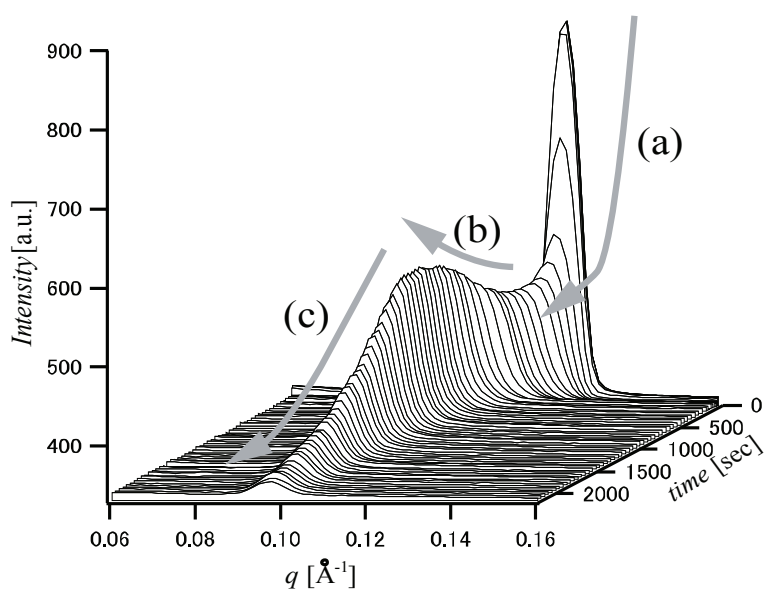

Fig.2 Time-resolved small-angle X-ray scattering profiles of hydrated stack of lipid bilayers. Three stages of the hydration kinetics are observed: (a) water penetration between bilayers reduces the peak intensity, (b) the peak position shift to lower- $q$ and the peak intensity recovers, and (c) the peak position is constant but the intensity decreases monotonically.

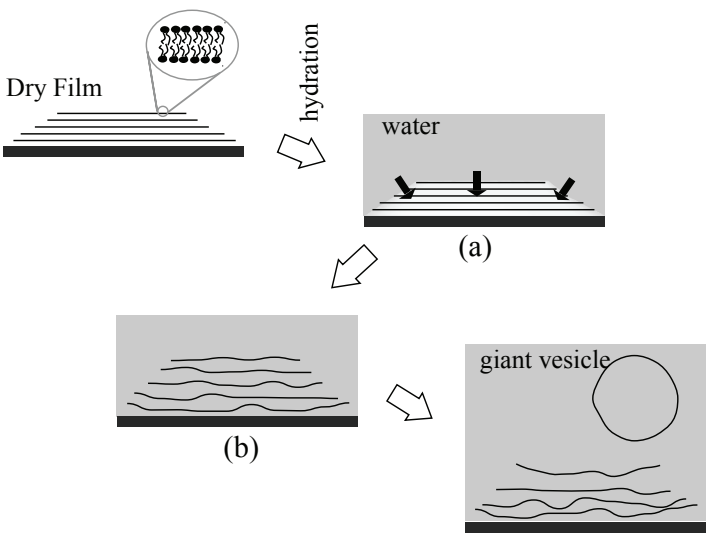

(c)

Fig.3 The hydration process of stacked lipid bilayers. (a) Soon after the hydration, water molecules penetrate between bilayers. (b) The lipid stack swells to a quasi-stable state. (c) The bilayers gradually peel off from the outermost layer and become giant vesicles.

ヤイアントベシクルが形成されていることも確認 された.とくにこの実験結果で興味深いのは，ジ ヤイアントベシクルが形成するまでの水和過程が 3 段 階のキネティクスを経て進むということである. Bragg ピークの位置から膜間距離を, 強度や幅からその秩 序度や積層枚数を見積もることにより, その 3 段階の キネティクスの解析を行うと, この水和過程は

(a)膜間への水の浸透

(b)膜間が膨潤し，一定の膜間距離を保ちつつ積

層したままといら準安定構造へと緩和

(c)膜が徐々に剥離していく

といらように進むことが明らかになった. 水和過程の模 式図を Fig.3 に示す. とくに重要なのは, 水和後も基 板上に積層したままの膜の状態が比較的長い時間 準安定に存在し, 膜の剥離が最外膜からのみ(もちろ ん理想的にはであるが)おこっているということである. これによって一枚ずつ膜がはがれて, さらに膜の端 は水中で不安定なのでそれが閉じることで単層のジ 
ヤイアントベシクルとなるのである.

さらに我々はここで観測された脂質膜の剥離現象 を, 膜同士に働く相互作用を考慮したモデルを立て ることで説明を行った。 そこで示唆されたことは，この 剥離現象を大きく支配しているのが「熱摇らぎによ る膜の波うちダイナミクス」[6]であるということ である。つまり波打ち運動により隣り同士の膜が ぶつかり合い，それによって実効的に $\mu \mathrm{m}$ スケー ルまで働くような大きな斥力が膜を剥がすという ことがわかった。

脂質がゲル相をとる場合にも同様の観測を行っ たところ, Fig.1 (b)に示寸ようなラフな Film が水 和された時は, 膜間に水が浸透し膨潤する過程は 観測されるが液晶相の時に見られたような膜の剥 離過程は観測されないということがわかった。こ れはゲル相の dry film を水和してもジャイアント ベシクルが形成しないという事実ともよくあう結 果である．液晶相と同様にモデルによる議論を行 ったことでわかったのは，ゲル相ではアシル鎖の 結晶化により膜が硬いため, 熱摇らぎによる波打 ちの効果が小さく, 膜が剥離するのに十分な斥力 が働かないということであった。

本研究では積層膜からジャイアントベシクルへ の構造転移のメカニズムを形成過程のキネティク スから迫ったが，そこからわかるのは，ジャイア ントベシクルが効率的に形成されるのには，初期 状態である dry film のテラス構造と水和された時 に一枚ずつ膜が剥がれるというキネティクスが重 要であるということである.

このメカニズムの理解は，より効率的にジャイ アントベシクルを形成する方法の提案へと発展す る.つまりテラス状に形成した脂質膜の膜間に塩 や糖を含有させておき，それを純水で水和するこ とで最外膜に大きな浸透圧を誘起できる。 それが 膜の波打ちによる质力と合わさることで，より十 分に最外膜をひき剥がす力となって, ジャイアン トベシクルが効率的に形成されるだろうというも のである. 実際に塩を用いて研究を行った結果, 塩がない場合にはジャイアントベシクルはある程 度多重膜のベシクルも混ざって形成されるが，塩 の含有下ではほとんど単層のものばかりが形成さ れるということがわかった[7]. 本方法はジャイア ントベシクルを細胞モデルとして使用するような 研究に大変有用であろう.

\section{3. 今後に向けて}

3.1. 脂質膜の形態形成メカニズム

これまでの研究により, リン脂質ジャイアント ベシクルといった “準安定状態に強く束縛された 構造”が形成するメカニズムの理解には，「初期構 造」の決定と「構造形成の緩和挙動」の理解が重 要であることがわかる。しかしこれまでの脂質膜 に関する研究は平衡状態に関するものが多く, 非 平衡な構造形成キネティクスに関してはまだまだ 理解されていない部分が多い.

しかし，実際の生体中においても様々な脂質膜
形態は非平衡な条件のもとで形成されていること を考えると，上のような発想は多くの場合に適用 でき，脂質膜の構造形成をその形成過程のキネテ イクスに注目して研究を行うという視点は今後よ り重要となってくると考えられる，私は今後，こ の発想を発展させることで, ジャイアントベシク ルだけでなく脂質膜系でみられる様々な膜形態の 形成メカニズムに迫っていきたい。さらにこれま での研究で示唆されたように, 膜の形態形成キネ ティクスは膜の波打ちなど熱摇らぎによるダイナ ミクスに支配されている。より原理的に脂質膜の 形態形成をキネティクスから理解するには，熱摇 らぎ等による膜のダイナミクスがどのように全体 の形態形成キネティクスを支配しているのかを理 解することも重要である.

とくに実際の生体膜では数千もの脂質分子が混 合することで膜を形成していることが知られ，さ らに組織によっては特異的にある脂質が濃縮され ていることも知られている。このことから脂質分 子の化学種がその膜の形態形成に重要であるとい うことが主に分子生物学の分野から指摘されてい る。そこで，これまでにわれわれが行ってきた一 成分だけでできた膜の形態形成だけでなく, 複数 の脂質がある場合にはどのようにそれぞれの脂質 が役割を果たしながら膜の形態形成が行われるの かということを，平衡構造と非平衡な形態形成キ ネティクス両面から明らかにしていくことは，ソ フトマター物理学から実際の生体膜に迫っていく 上で不可欠なステップだと言えよう。こういった ステップを積み重ねることで将来的には例えばな ぜクリステ（ミトコンドリア内膜）のような構造 が特異的脂質の集積により生まれるのか，なぜ細 胞は基本的に $\mu \mathrm{m}$ サイズなのかといった命題にチ ヤレンジしていきたいと考えている.

たとえば私が最近注目しているのは脂質膜の内 膜外膜非対称性である. 複数の脂質を混合した際 に自発的に形成される二重膜では，ベシクルが数 十 $\mathrm{nm}$ スケールの小さなものであったり，それぞ れの脂質の物理化学的な性質が極めて大きく異な ったりしない限り，内膜と外膜の脂質組成は同じ になる。一方で生体膜では二重膜の内膜と外膜で 脂質組成が異なっており，それによりうまく膜環 境を作りだしている。生体中ではこの準安定状態 と思われる非対称性をフリッパーゼなどのタンパ ク質を使って制御していることが分かっている. しかし一方でこの非対称性は, 脂質膜の物性とし て自発的に生まれることはないのだろうか，また はジャイアントベシクルなどの人工膜上において 作り出すことはできるのだろうか. 非対称膜の形 態形成キネティクスに注目することで，非対称性 における脂質膜の物理的性質の重要性を明らかに できると期待している.

\section{2. 中性子の利用}

われわれはこれまでX線を用いた時分割測定に より膜構造の形成キネティクスを観測してきた. 
これは放射光による強度の強いX線を利用するこ とで可能になったものであるが，一方で試料を X 線向きに調整（一種類の脂質のみを用いて作成） する必要があった。これはX線では電子密度分布 しか測れないため，わずかに化学種の異なる脂質 分子を見分けることができない為である。一方， 脂質分子や溶媒を重水素化することで任意にコン トラストをつけて観測の行える中性子散乱は，X 線が白黒写真なのに対してカラ一写真であるとい えよう。つまり中性子散乱を用いれば，X線散乱 では不可能であった，複数の脂質分子が存在する ときにそれぞれの脂質がどのようなキネティクス を見せるのか，またそれによって膜全体のキネテ イクスが一成分の時とどのように変化するのかと いった，より実際の生体膜に近い環境での脂質膜 の形態形成キネティクスを観測することができる と期待される。

もつとも現時点では我々がこれまでに行ってき たような数秒程度の時分割測定を中性子で行うこ とは強度の問題があって難しい。 そこでまずは比 較的遅いキネティクスの観測に焦点を当てていく べきである。たとえば最近京都大学の中野らは， 時分割中性子小角散乱を用いることにより，脂質 二重膜の内膜と外膜での脂質分子の入れ替わりの キネティクスを観測している[8].これはこのキネ ティクスが数分から数十分かかる遅いものである ため可能となっている，将来的には大強度中性子 源と装置開発によってこれまでに行ってきたよう な早いキネティクスまで観測したいというのが 我々の夢である。

また，熱摇らぎによるダイナミクスと形態形成 キネティクスの関係を探るには中性子スピンエコ 一を用いるのがよい。大強度中性子源の発展によ りスピンエコーも時分割で行えるようになれば, 非平衡な形態形成の過程において熱摇らぎダイナ ミクスがどう変化していくのか，それがどう形態 形成に影響を及ぼすのか明らかにできるだるう。

\section{4.おわりに}

脂質膜にとどまらず, DNA やタンパク質などの 生体分子や界面活性剂, 高分子といったソフトマ ターは固体とは異なり数〜数百 $\mathrm{nm}$ スケールでミ セルや膜といった中間階層構造をもつため, 一般 的に平衡構造に緩和するのが非常に遅く，数日以 上かかることも多い。これは，こういった物質に おいてもジャイアントベシクルのように非平衡な 過程で準安定状態に強くトラップされた構造が多 く存在するであるうということを示唆している. しかし，これらソフトマターの研究はまだまだ歴 史が浅く，多くは平衡状態の理解にとどまってい る.こういった準安定構造の形成メカニズムを明 らかにするにあたってはその形成キネティクスを 理解することが重要である。そこで今後はより一 層キネティクスの観測に対する重要性が増してく るだろう。その中で，重水素化によるコントラス 卜法をらまく利用した時分割中性子小角散乱や，
熱摇らぎによる超分子のダイナミクスを観測でき る中性子スピンエコー法は，他ではできないよう な新しい現象の観測に役立つと期待される.

\section{謝辞}

本研究は京都大学理学研究科の吉川研一教授, お よび高エネルギ一加速器研究機構の瀬戸秀紀教授 のご指導のもとで行ってまいりました。その他多 くの方に関わっていただきました。ここに厚くお 礼申し上げます。また本研究は日本学術振興会科 学研究費補助金（特別研究員奨励費 19・2774）の ご支援のもと行われました。

\section{参考文献}

[1] A. D. Bangham, M. M. Standish and J. C. Watkins, J. Mol. Biol. 13, 238 (1965).

[2] S-i. M. Nomura, K. Tsumoto, T. Hamada, K. Akiyoshi, Y. Nakatani, and K. Yoshikawa, ChemBioChem, 4, 1172 (2003).

[3] M. Hishida, H. Seto and K. Yoshikawa, Chem. Phys. Lett. 411, 267 (2005).

[4] M. Hishida, H. Seto, P. Kaewsaiha, H. Matsuoka and K. Yoshikawa, Colloid Surf. A, 284-285, 444 (2006).

[5] M. Hishida, H. Seto, N. L. Yamada and K. Yoshikawa, Chem. Phys. Lett. 455, 297 (2008).

[6] W. Helfrich, Z. Naturforsch, 33a, 305 (1978).

[7] N. L. Yamada, M. Hishida, H. Seto, K. Tsumoto and T. Yoshimura, Europhys. Lett. 80, 48002 (2007).

[8] M. Nakano, M. Fukuda, T. Kudo, H. Endo and T. Handa, Phys. Rev. Lett. 98, 238101 (2007). 